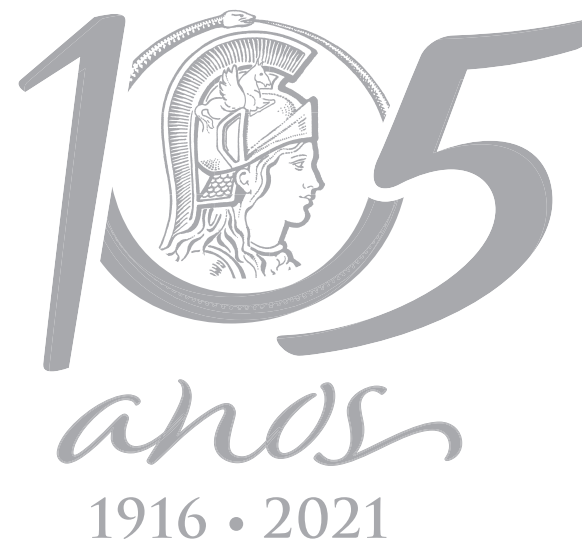

$1916 \cdot 2021$

\title{
Mycobiota on exoskeleton debris of Neohelice granulata in an alkaline-sodic salt marsh: in vitro enzyme ability at different temperatures and pH
}

\author{
NATALIA A. FERRERI, LORENA A. ELIAADES, MARIO C.N. SAPARRAT, TAMARA M. \\ LEDESMA, LETICIA RUSSO \& MARTA N. CABELLO
}

\begin{abstract}
This study analysed the mycobiota on exoskeleton debris of the crab Neohelice granulata collected from an alkaline salt marsh and assessed the in vitro enzyme ability of selected isolates at different temperatures and pH. Exoskeleton fragments were incubated in moist chambers on paper and on agar medium. Growth and enzyme ability of selected fungi were also evaluated in agar media with $0.5 \%$ casein, $1 \%$ Tween $^{\circ} 20$, and Chitin-Azure by the production of a halo/growth ratio. We identified 22 fungal species using both methods. Since the two isolation methods added information to one another, both ones are necessary to recover the cultivable mycobiota associated with the exoskeleton debris. All fungi showed greater levels of enzyme activity in alkaline than acid medium with Tween 20 . The halo diameter on casein and chitin varied according to the fungal isolate and $\mathrm{pH}$. Most fungi had a larger halo at $4^{\circ} \mathrm{C}$ than at the other temperatures tested. Clonostachys rosea showed the greatest activity in all media at 4으. We conclude that exoskeletons of the $N$. granulata are a source of fungi able to produce enzyme activities that show differences upon incubation conditions to which they are cultivated such as ones including specific temperatures and $\mathrm{pH}$ values.
\end{abstract}

Key words: crab exoskeletons, diversity, enzyme activity, fungal decomposers.

\section{INTRODUCTION}

Extreme ecosystems are currently considered the most interesting places to investigate microorganisms and/or their roles and enzymes, mainly due to the stressful conditions in which they grow. For several years, our working group and other researchers at world level are analyzing in different stressful ecosystems specific organic materials as source of fungi to identify isolates with specific physiological behaviours and able to synthetize enzymes, that might be active under stressful conditions and therefore to be evaluated as potential tools for biotechnological applications (Saparrat et al. 2007, Franco et al. 2018). An example of this type of ecosystem, from which there is not any information available, is a brackish salt marsh called "cangrejal", which is located at Campos del Tuyú National Park, in the eastern part of the Salado Sedimentary Basin

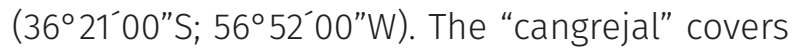
lowlands of less than 4 meters above sea level, with a large proportion of flooded lands and drainage channels. Due to the periodic flooding caused by the tides, there is a constant supply of brackish water in this area and therefore a high salt content (30.40 and $35.8 \mathrm{~ms} / \mathrm{cm}$, Carol et al. 2015), which generates saline-sodic soils with pH between 7.5 and 9 (Beade 1981). This area is characterized by the presence of high densities of the burrowing semiterrestrial crab Neohelice granulata (Dana 1851) (syn. Chasmagnathus granulatus), which is endemic to tropical and 
subtropical estuaries of South America (Boschi 1964, Spivak 2010). The endo- and exocuticle of crustacean exoskeletons are constituted by several compounds, mainly proteins (15-40\%), chitin (20-40\%), lipids (1-17\%), and different calcium, phosphorous, and magnesium salts, as well as $\beta$-carotene (Stevenson 1985, Lage-Yusty et al. 2011, Spivak 2016). Therefore, exoskeletons are one of the major animal sources of organic matter in soils of brackish salt marshes such as Campos del Tuyú National Park.

The structure of $N$. granulata populations, including features of their life history, reproduction, feeding behaviour, and ecological role, have been studied in numerous environments characterized by low or fluctuating salinity (Botto et al. 2006, Mendez-Casariego et al. 2011). Neohelice granulata is a semiterrestrial burrowing crab endemic from tropical and subtropical estuaries in South America. These species occur in the southwestern Atlantic Ocean in Brazil (from Río de Janeiro $22^{\circ} 57^{\prime} S$, $52^{\circ} 32^{\prime} W$, to Rio Grande do Sul, Uruguay and San José Gulf, Northern Patagonia, Argentina $42^{\circ} 25^{\prime} \mathrm{S}$, $64^{\circ} 36^{\prime} W$ ) (Spivak 2010). Dense populations of N. granulata inhabit almost all zones of the intertidal, the soft bare sediments flats and areas with the cordgrass Spartina densiflora, Spartina alterniflora and Sarcocornia perennis (formerly known as Salicornia ambigua) (Botto et al. 2005, Bortolus 2006). This crab constructs vertical burrows of up to $10 \mathrm{~cm}$ of diameter that can reach up to $1 \mathrm{~m}$ depth in vegetated marshes. The burrows remain open during high tide periods and generally remain full of water during low tide. Furthermore, these burrows act as passive traps of sediment and detritus in open mud flats. Burrowing activity may also change sediment characteristics (Botto et al. 2006, Mendez-Casariego et al. 2011). It is estimated that organisms annually produce 100 to 200 billion tons of exoskeleton remains, constituting a huge amount of biomass in lake waters and bottom sediments (Swiontek Brzezinska et al. 2008). Chitinolytic microorganisms play an important role in the degradation of the exoskeleton, being bacteria and fungi capable of producing chitinolytic enzymes, which degrades exoskeletons. However, the fate of $N$. granulata exoskeletons in these stressful environments and the microorganisms involved in their decomposition are still unknown.

During the microbial degradation of the organic compounds of $N$. granulata exoskeletons, enzyme complexes such as those catalysing lipolysis, proteolysis, and chitinolysis might be involved. Although fungi have been considered as key contributors to detritus-based food webs in salt marshes (Torzilli et al. 2006), according to Swiontek Brzezinska et al. (2013) chitinolytic fungi and bacteria play an important role in the degradation of shrimp waste. However, there is no information hitherto available on the fungi associated with $N$. granulata and their role in the degradation of the exoskeleton compounds. Therefore, our aims were to study the diversity of cultivable microfungi that grow on exoskeleton debris of this crab collected at Campos del Tuyú National Park and to analyse the ability of selected isolates to grow on agar media and produce lytic enzyme systems at different incubation temperatures and $\mathrm{pH}$ of the media. We hypothesized that crab exoskeleton debris found in brackish salt marshs from campos del Tuyú National Park (Argentina) might be a source for the isolation of fungi able to produce enzymes highly active at specific temperatures or $\mathrm{pH}$ values, which are related to the environmental characteristics of fungal source and to environment where were collected as well as to fungal optima for enzymatic activity. These enzymes might be used as biotechnological tools for several industrial processes (Elíades et al. 2010, Franco et al. 2018). 


\section{MATERIALS AND METHODS}

\section{Study area and sampling}

Exoskeletons of $N$. granulata were collected from an area of "cangrejales" in Bahía de Samborombón using a random sampling method. This methodology requires that each sample must have equal opportunity to be selected. The sampling was carried out randomlyin three areas of $200 \mathrm{~m}^{2}$ of different "cangrejales", where exoskeletons were collected on ground surface or on the vegetation cover. This area belongs to Campos del Tuyú National Park and is located in the southwestern region of La Plata River estuary, General Lavalle ( $36^{\circ} 21^{\prime} \mathrm{S}, 56^{\circ} 52^{\prime} \mathrm{W}$ ), Buenos Aires, Argentina (Figure 1). The climate and characteristics of the study area were previously described by Volpedo et al. (2005). The physical and chemical features of the soil in the study area were determined according to
SAMLA (2004) and PROMAR-AACS (1991), and are shown in Table I.

Sampled exoskeletons were stored in plastic bags at $4^{\circ} \mathrm{C}$ until processing after four days (Dick et al. 1996). In the laboratory, they were fragmented into small pieces (approx. $5 \mathrm{~mm}^{2}$ ). Thereafter, exoskeletons were washed with sterile distilled water to remove soil traces and left to dry in a petri dish with filter paper, as shown in Figure 2a-b.

\section{In vitro incubation of exoskeletons, fungal isolation and diversity analyses}

The following methods were employed for fungal isolation: (i) moist chambers: five exoskeleton pieces per plate were incubated in Petri dishes (90 $\mathrm{mm}$ diam.) with moistened filter paper at 250 C $(n=60)$, and (ii) cultivation on solid media of exoskeletons pieces previously washed with sterile water and fragmented as described above (Parkinson \& Williams 1961). For the latter

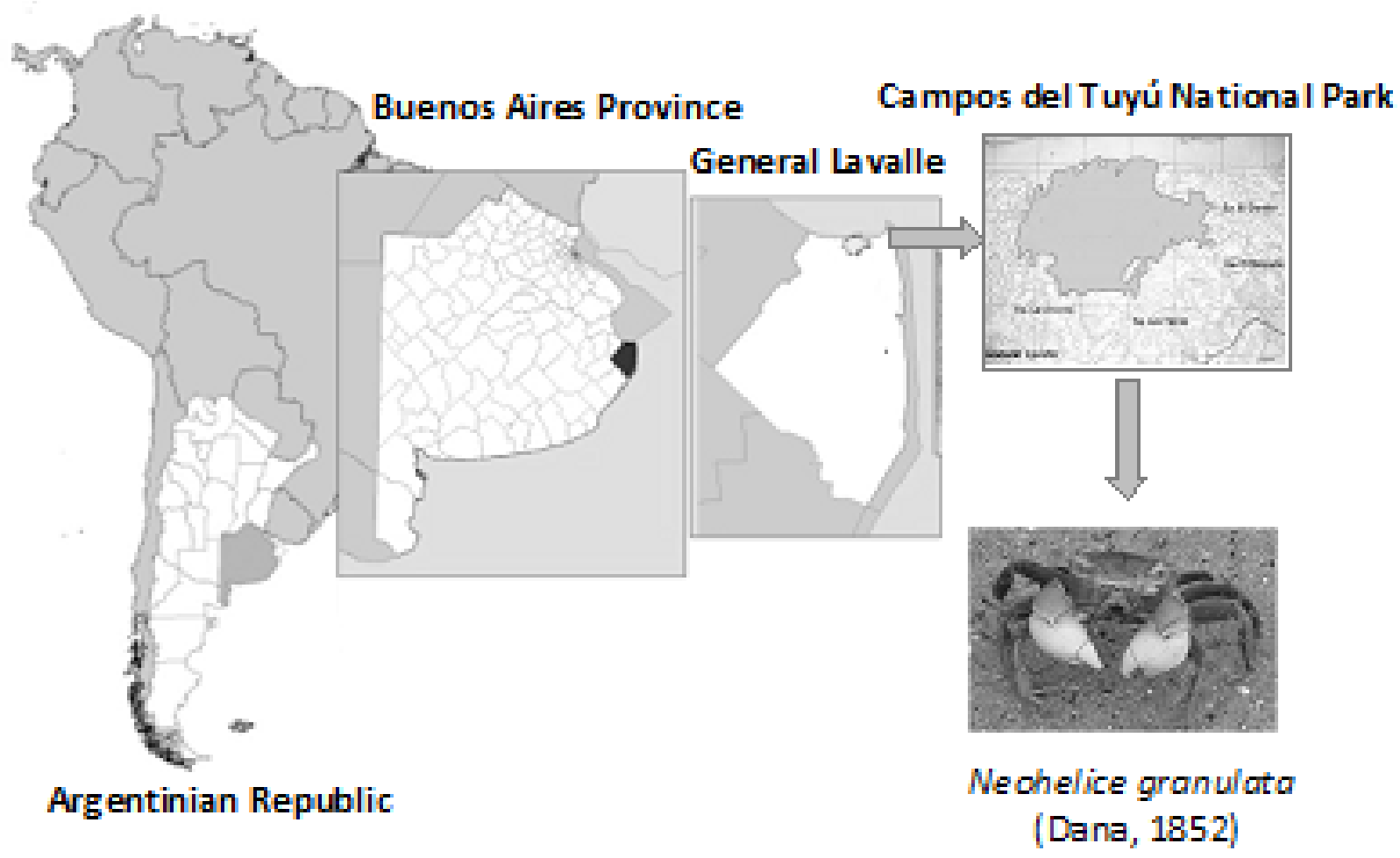

Figure 1. Location of the sampling site in Campos del Tuyú National Park, General Lavalle, Buenos Aires, Argentina. 
method, pieces were left to dry for $24 \mathrm{~h}$ on filter paper discs to avoid bacterial and yeast growth and then plated according to Widden \& Parkinson (1973). Sixty pieces were inoculated onto 12 Petri dishes containing cornmeal, yeast, glucose agar (CMYG) with $0.5 \%$ streptomycin and $0.25 \%$ chloramphenicol (washing and particle technique). Plates were incubated at $25^{\circ} \mathrm{C}$ until the development of fungal colonies. For microscopic observation of morphological featuresof fungi grown in both methods, Malt Extract Agar (MEA) slide cultures were prepared and mounted with lactophenol cotton blue. Fungi were identified according to Carmichael et al. 1980, Domsch et al. 1993, and Ellis 1971 (Table II), and deposited in the culture collection of "Instituto Spegazzini" (LPSC). Stock cultures were maintained on $2 \%\left(\mathrm{~W} \mathrm{v}^{-1}\right)$ MEA slants at $4^{\circ} \mathrm{C}$.

In the case of the moist chamber technique, each exoskeleton piece was considered a

Table I. Soil physical and chemical features.

\begin{tabular}{|c|c|}
\hline Characteristic & Value $^{\mathbf{a}}$ \\
\hline $\mathrm{pH}$ & $8.1 \pm 0.14$ \\
\hline Organic C \% & $1.24 \pm 0.11$ \\
\hline Organic matter \% & $2.14 \pm 0.18$ \\
\hline Total N \% & $0.13 \pm 0.01$ \\
\hline Total P mg/kg & $559.67 \pm 17.21$ \\
\hline Electric conductivity (dS/m) & $52.51 \pm 10.87$ \\
\hline $\mathrm{K}^{+}$(meq/l) & $0.58 \pm 0.09$ \\
\hline Ca $^{2+}+$ Mg $^{2+}$ (meq/l) & $327 \pm 73.88$ \\
\hline Na $^{+}$(meq/l) & $844.23 \pm 249.68$ \\
\hline RAS (sodium adsorption ratio) & $64.34 \pm 13.62$ \\
\hline Texture $^{2}$ & clayey/argillaceous \\
\hline
\end{tabular}

${ }^{\mathrm{a}}$ Values are means of three representative replicate samples \pm standard deviation. sampling unit. The percentage frequency of each fungal species was calculated as:

$\underline{\text { Number of exoskeleton pieces colonized by a fungal species }} \times 100$ Total number of pieces analysed

The frequency was calculated based on the number of times a species occurred on the exoskeleton pieces. We also estimated the species richness (S) and evenness (J) of the mycobiota and he diversity index of ShannonWeiner $\left(\mathrm{H}^{-}\right)$using the frequency of each fungal species (Magurran 1988, Cabello \& Arambarri 2002). The data were analysed with a oneway analysis of variance (ANOVA), followed by Tukey's test $(P<0.05)$.

\section{Growth and enzyme activity of selected isolates and their response to different incubation temperatures and $\mathrm{pH}$ of the media}

Agar plugs (6 mm diam.) obtained from each fungus growing on Oxoid CMA with $0.2 \%$ glucose were inoculated onto Petri dishes with agar media supplemented with $0.5 \%$ casein, $1 \%$, Tween 20 (polyoxyethylene sorbitan monolaurate Merck ${ }^{\oplus}$ ), and $0.08 \%$ ChitinAzure $^{\oplus}$ (Sigma ${ }^{\oplus}$, C3020) according to Hankin \& Anagnostakis 1975, Howard et al. 2003, and Koneman \& Roberts 1987, respectively. Three replicate plates of each culture medium per isolate were prepared. Dishes were incubated in the dark at $4 \pm 1^{\circ} \mathrm{C}, 16 \pm 1^{\circ} \mathrm{C}$ and $26 \pm 1^{\circ} \mathrm{C}$ for 7 or 20 days in the case of cultures on chitin medium. In addition, the effect of $\mathrm{pH}$ was evaluated using three replicates of each medium mentioned above with $\mathrm{pH} 5.0,8.0$, and 10, which were incubated in the dark at $26 \pm 1^{\circ} \mathrm{C}$ for 7 or 20 days in the case of cultures on chitin medium. The $\mathrm{pH}$ was adjusted after autoclaving using buffer solutions (Nagai et al. 1998). For each treatment, fungal growth was estimated by measuring the diameter $(\mathrm{cm})$ of each colony. The hydrolytic enzyme activity was estimated qualitatively by 
the presence of a clearance/precipitation halo due to hydrolase action. Results were expressed as mean values \pm standard deviation (SD) of the ratio between the hydrolytic halo and the colony diameter (Saparrat et al. 2008). The fungal growth and enzyme activity were compared with ANOVA and the differences between means were discriminated by Fisher's least-significantdifference multiple-range test $(P<0.05)$, using InfoStat software.

\section{RESULTS}

Twenty-two fungal taxa were recorded from the exoskeleton rests; 14 using the moist chamber technique and 17 from the cultivation of washed exoskeleton pieces on agar media (Table II). Nine taxa were recovered using both methods, being F. solani (moist chamber: $20.83 \%$ and cultivation on agar media: $35.83 \%$ ) and A. alternata (moist chamber: $13.33 \%$ and cultivation on agar media:

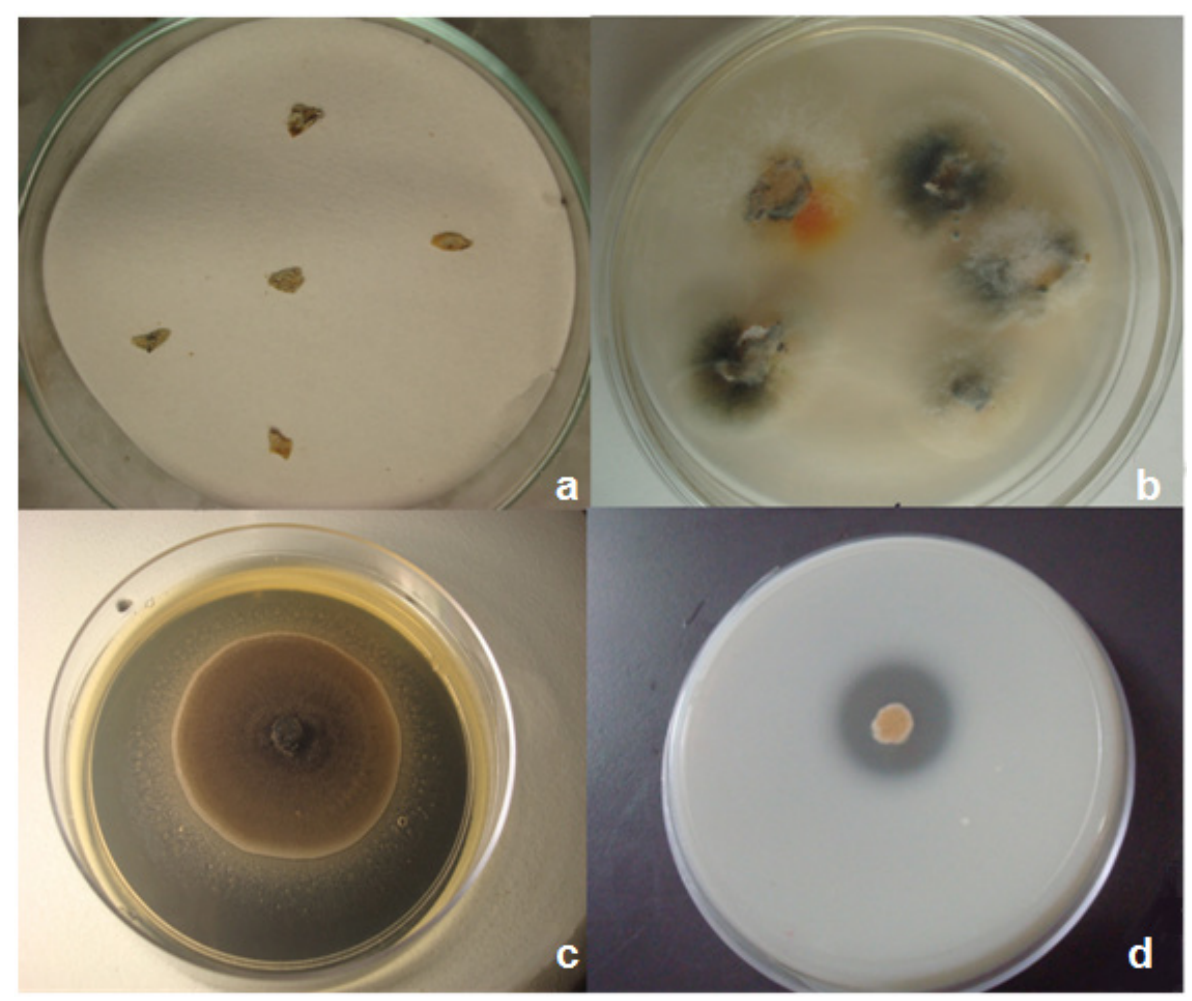

$35.83 \%)$ the most frequent ones. Five species were recorded exclusively on exoskeleton pieces incubated in moist chambers, in which a dematiaceous sterile mycelium was dominant. Eight taxa, including F. equiseti, were detected only from washed exoskeleton pieces cultivated on agar media. However, there were no significant differences between diversity and evenness indexes of the mycobiota obtained from exoskeleton pieces incubated in moist chambers ( $\left.\mathrm{H}^{\prime}: 1.86 ; \mathrm{E}: 0.48\right)$ and from washed exoskeletons cultivated on agar media ( $\mathrm{H}^{\prime}$ : 2.13, E: 0.51; P> 0.001).

All isolates grew on the three culture media at the incubation temperatures and $\mathrm{pH}$ tested, however, some strains showed a differential growth at certain incubation temperatures and/ or pH (Figure 3). The alkalization of the medium containing Tween 20 did not reduce the growth of F. equiseti LPSC 1423 and F. solani LPSC 1422. A similar response was observed for A. alternata LPSC 1244, F. solani LPSC 1422, and S. brevicaulis

Figure 2. a-b. Fungal isolation from exoskeleton debris of the crab Neohelice granulata. a. Development of fungal colonies on filter paper in moist chambers. b. Fungal colonies from washed exoskeleton pieces on CMYG culture medium. c. Lipolytic activity in agar media. d. Proteolytic activity in agar media. 
LPSC 1362 on casein. However, the latter fungus showed a greater colony diameter on chitin azure at pH 8 than under both acid and strong alkaline conditions. On the other hand, all fungi tested on three types of media revealed a greater colony diameter with the increase in incubation temperature (Figure 4).

The enzyme ability of the selected fungal species on specific media at three different
$\mathrm{pH}$ values and incubation temperatures is shown in Tables III and IV, respectively. All fungi tested showed higher activity on Tween 20 medium under alkaline than acidic pH values. Clonostachys rosea LPSC 1236 and S. brevicaulis LPSC 1236 showed the greatest halo/growth ratio at $\mathrm{pH}$ 10. However, some isolates were not able to hydrolyse Tween 20 at pH 5.0. Fusarium solani LPSC 1422 was the only fungus that

Table II. Frequency of the fungal taxa on exoskeleton debris according to the isolation method and their contribution to the Shannon-Weaver diversity index $\left(\mathrm{H}^{\prime}\right)$.

\begin{tabular}{|c|c|c|c|c|}
\hline \multirow{3}{*}{ Taxa } & \multicolumn{4}{|c|}{ Isolation source } \\
\hline & \multicolumn{2}{|c|}{ Moist chambers } & \multicolumn{2}{|c|}{ Agar media } \\
\hline & Frequency & $\begin{array}{l}\text { Contribution to } \mathrm{H} \\
\left(-p i \log _{2} \text { pi) }\right.\end{array}$ & Frequency & $\begin{array}{l}\text { Contribution to } \mathrm{H} \\
\quad\left(-p i \log _{2} \text { pi) }\right.\end{array}$ \\
\hline \multicolumn{5}{|l|}{ Ascomycota } \\
\hline Fusarium solani & 20.83 & 0.33 & 35.83 & 0.34 \\
\hline Alternaria alternata & 13.33 & 0.28 & 35.83 & 0.34 \\
\hline Cladosporium cladosporioides & 1.67 & 0.07 & 1.67 & 0.05 \\
\hline Fusarium sp & 1.67 & 0.07 & 10.00 & 0.18 \\
\hline Purpureocillium lilacinum & 1.67 & 0.07 & 4.17 & 0.10 \\
\hline Scopulariopsis brevicaulis & 1.67 & 0.07 & & \\
\hline Acremonium kiliense & 0.83 & 0.04 & & \\
\hline Chaetomium globosum & 0.83 & 0.04 & & \\
\hline Fusarium equiseti & & & 24.17 & 0.30 \\
\hline Fusarium graminearum & & & 10.00 & 0.18 \\
\hline Clonostachys rosea & & & 4.17 & 0.10 \\
\hline Penicillium sp & 0.83 & 0.04 & 4.17 & 0.10 \\
\hline Aspergillus sp & & & 0.83 & 0.03 \\
\hline Beauveria sp & & & 0.83 & 0.03 \\
\hline Penicillium rubrum & & & 0.83 & 0.03 \\
\hline Phoma sp & & & 0.83 & 0.03 \\
\hline \multicolumn{5}{|l|}{ Mucoromycota } \\
\hline Mucor sp & 1.67 & 0.07 & 0.83 & 0.03 \\
\hline Rhizopus stolonifer & & & 4.17 & 0.10 \\
\hline \multicolumn{5}{|l|}{ Mycelia sterilia } \\
\hline Dematiaceous sterile mycelium 1 & 34.17 & 0.37 & & \\
\hline Dematiaceous sterile mycelium 2 & 2.50 & 0.10 & 0.83 & 0.03 \\
\hline Hyaline sterile mycelium 1 & 12.50 & 0.27 & & \\
\hline Hyaline sterile mycelium 2 & 0.83 & 0.04 & 7.50 & 0.15 \\
\hline
\end{tabular}


was not able to hydrolyse casein at the three $\mathrm{pH}$ values analysed. The halo/growth ratio on casein varied depending on the fungal isolate and $\mathrm{pH}$ value. Alternaria alternata LPSC 1244 showed proteolytic activity at pH 5.0, whereas P. lilacinum LPSC 1236 and S. brevicaulis LPSC 1362 at alkaline pH. While F. equiseti LPSC 1422
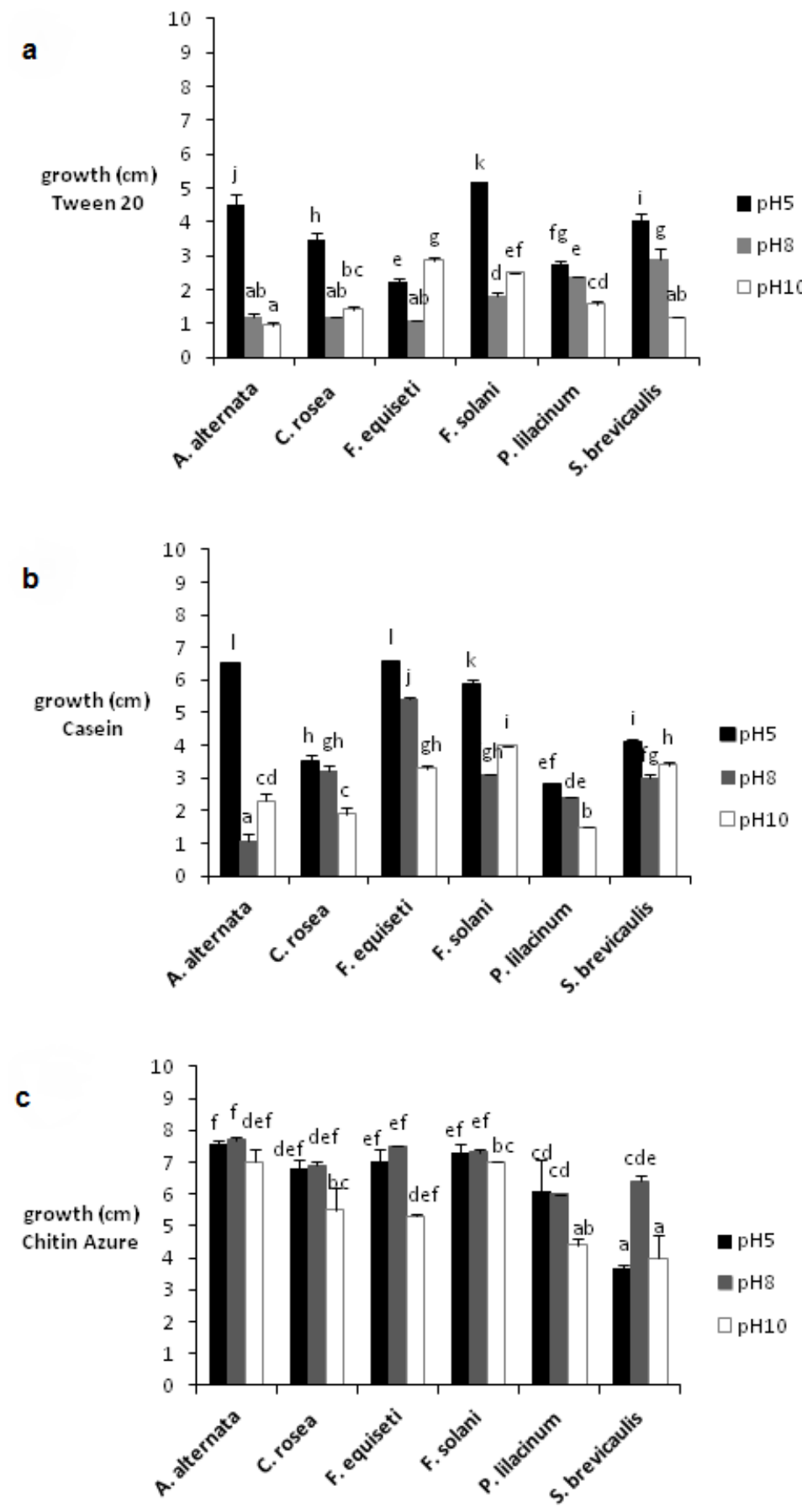

only revealed chitinolytic activity at $\mathrm{pH} 10, \mathrm{~A}$. alternata LPSC 1244 failed to decolorize the medium supplemented with chitin azure at the three $\mathrm{pH}$ values tested. The halo/growth ratios of the other fungi did not differ considerably at $\mathrm{pH}$ 8. On the other hand, growth and enzyme activity showed a different response

Figure 3. Colony growth of the selected fungal species on specific substrates (a, Tween ${ }^{\circledR} 20$; b, casein; c, Chitin-Azure ${ }^{\circledR}$ ) at $26^{\circ} \mathrm{C}$ and pH 5 (black bars), pH 8 (grey bars), and pH 10 (white bars). The data are means of three replicates $\pm \mathrm{SD}$; the same

$\square \mathrm{pH} 10$ letters above the bars indicate non-significant differences (multiple-range-Test; $\mathrm{P} \leq \mathbf{0 . 0 5}$ ). 
to temperature. All isolates varied their halo/ growth ratios in the three substrates analysed according to the incubation temperature, being in most fungi greater at $4^{\circ} \mathrm{C}$ than at the other incubation temperatures tested (Table IV).

\section{DISCUSSION}

Two isolation methods were used to recover the cultivable mycobiota associated with the moult of $N$. granulata inhabiting a brackish salt marsh in Campos del Tuyú National Park (Argentina), which were complementary because they revealed specific taxa. This fact can be closely

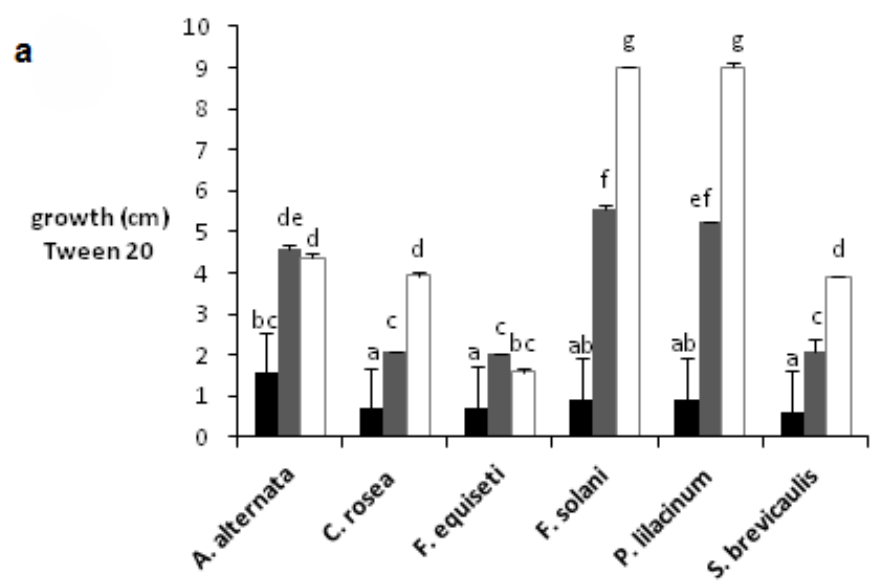

Figure 4. Colony growth of the selected fungal species on agar medium with specific substrates (a, Tween ${ }^{\oplus} 20$; b, casein; c, Chitin-Azure ${ }^{\oplus}$ ) at $\mathrm{pH} 7$ and three different temperatures: $4^{\circ} \mathrm{C}$ (black

$\square$ T3 $26^{\circ} \mathrm{C}$ (white bars). The data are means of three replicates \pm $\mathrm{SD}$; the same letters above the bars indicate non-significant differences (multiple-rangeTest; $\mathrm{P} \leq 0.05$ ).
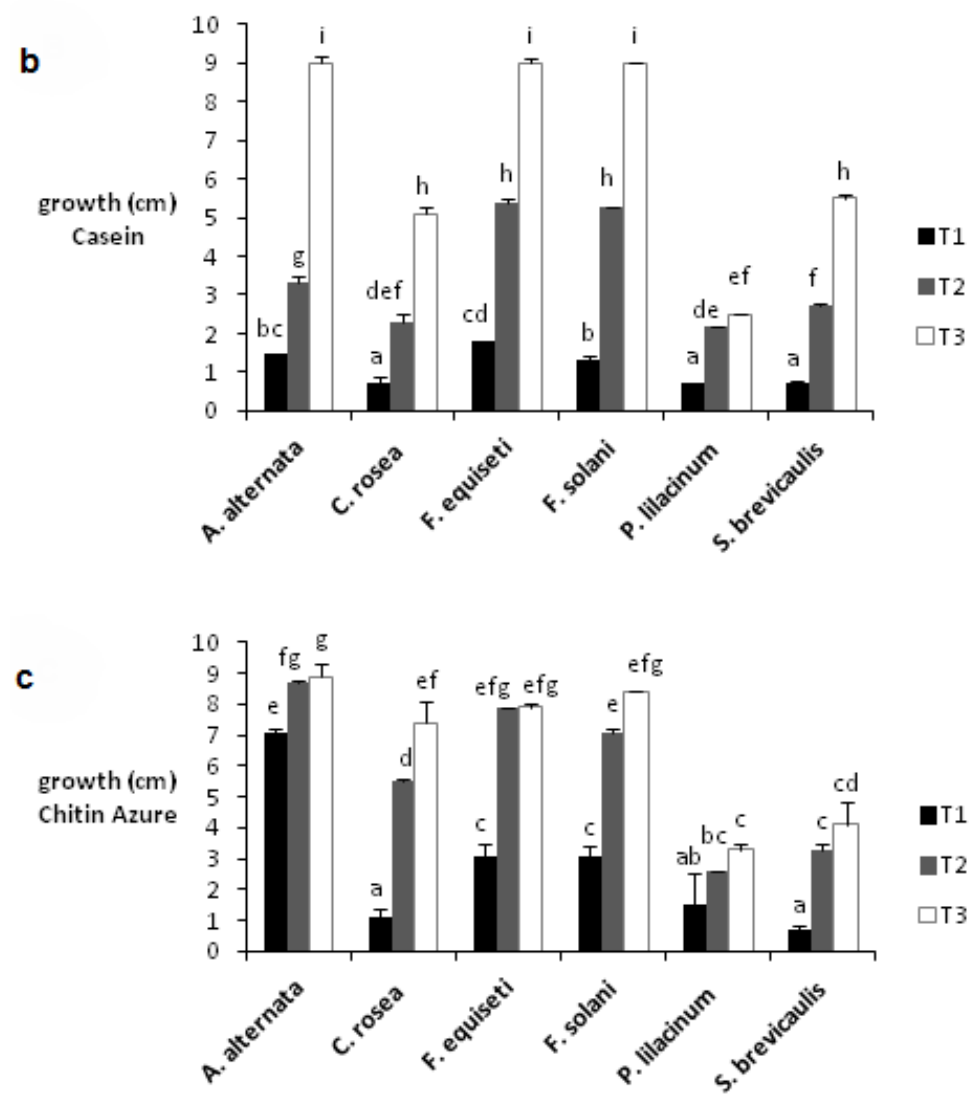
related to the existence of specific limitations for each isolation method, being physiological requirements (including nutritional ones) the critical aspects such as suggested by Mallo et al. (2017). In this sense, the washing technique has been suggested be far more efficient to isolate actively growing microfungi on isolation source (Cabello \& Arambarri 2002). Oppositely, moist chamber technique is further dependent on the spores available and adhered on the isolation source, which must be viable and can germinate on the incubation conditions as well as their hyphae grow using cellulosic materials such as filter paper, which is highly different to the chemical nature of the exoskeleton debris of $\mathrm{N}$. granulata. Nayar \& Jothish (2013) reported that some propagules such as ones from Ascomycota show specific difficulties to germinate. Therefore, since a relationship between isolation sources of the fungi and their metabolic pathways might exist (Franco et al. 2018), it is probable that the fungi recovered from exoskeleton debris applying each isolation method can be different. This suggests that it is important to use multiple isolation methods to recover fungi from exoskeleton debris of $N$. granulata. However, the estimated fungal richness and diversity did not differ between the isolation methods used, which is in accordance with other previous finding analyzing the same parameters in alkali-tolerant mycobiota of Distichlis spicata (Poaceae) litter in alkaline soils from Buenos Aires Province (Elíades et al. 2014). Specifically, Purpureocillium lilacinum, Clonostachys rosea, Acremonium kiliense were previously reported also from those samples of a saline-sodic soil (Elíades et al. 2014) with similar characteristics to the soil found in Campos del Tuyú National Park.

All fungi isolated from $N$. granulata debris were able to decompose the specific carbon substrates that are representative of the structural components of the crab exoskeleton, and showed proteolytic, lipolytic, and chitinolytic activity in agar media. Previous findings suggest that metabolic abilities of the fungi, including synthesis of lytic enzymes such as proteases, lipases and chitinases, are adaptive and of ecological significance, which also are highly dependent upon each isolate and so revealing intraspecific physiological variability in different taxa according their isolation source (Fenice et al. 1997, Franco et al. 2018, Barrera et al. 2019). Also, the behaviour of each fungal strain in

Table III. In vitro extracellular ability of six selected fungi grown on agar media supplemented with Tween ${ }^{\oplus} 20$, casein and Chitin-Azure ${ }^{\oplus}$ at three different $\mathrm{pH}$ and $26^{\circ} \mathrm{C}$. The same letters indicate non-significant differences ( $\mathrm{P} \leq$ 0.05).

\begin{tabular}{|c|c|c|c|c|c|c|c|c|c|}
\hline \multirow[b]{4}{*}{ A. alternata } & \multicolumn{9}{|c|}{ Enzyme ability (halo/growth) } \\
\hline & \multicolumn{3}{|c|}{ Tween 20} & \multicolumn{3}{|c|}{ Casein } & \multicolumn{3}{|c|}{ Chitin Azure } \\
\hline & pH 5 & pH 8 & pH 10 & pH 5 & pH 8 & pH 10 & pH 5 & pH 8 & pH 10 \\
\hline & $0 \mathrm{a}$ & $1 \mathrm{~b}$ & $1.7 \mathrm{~h}$ & $1.1 \mathrm{C}$ & $0 \mathrm{a}$ & $0 \mathrm{a}$ & $0 \mathrm{a}$ & $0 \mathrm{a}$ & $0 \mathrm{a}$ \\
\hline C. rosea & $1.1 \mathrm{C}$ & $1.7 \mathrm{ih}$ & $2.7 \mathrm{j}$ & $1.1 \mathrm{C}$ & $1.1 \mathrm{C}$ & $0 \mathrm{a}$ & 1 def & $1 \mathrm{def}$ & $0.8 \mathrm{c}$ \\
\hline F. equiseti & $1,1 \mathrm{C}$ & $1.8 \mathrm{i}$ & $1.27 \mathrm{e}$ & $1 \mathrm{~b}$ & $1.1 \mathrm{C}$ & $0 \mathrm{a}$ & $0 \mathrm{a}$ & $0 \mathrm{a}$ & $1.7 \mathrm{~h}$ \\
\hline F. solani & $0 \mathrm{a}$ & $1.37 \mathrm{gf}$ & $1.5 \mathrm{~g}$ & $0 \mathrm{a}$ & $0 \mathrm{a}$ & $0 \mathrm{a}$ & $0.9 \mathrm{~cd}$ & $1 \mathrm{def}$ & $1.3 \mathrm{~g}$ \\
\hline P. lilacinum & $0 \mathrm{a}$ & $1.1 \mathrm{C}$ & $1.2 \mathrm{~d}$ & $0 \mathrm{a}$ & $1.1 \mathrm{C}$ & $1.2 \mathrm{~d}$ & $0.9 \mathrm{~cd}$ & $0.93 \mathrm{de}$ & $0.67 b$ \\
\hline S. brevicaulis & $1.17 \mathrm{~d}$ & 1.2 & $2.8 \mathrm{k}$ & $0 \mathrm{a}$ & $1.2 \mathrm{~d}$ & $1.3 \mathrm{e}$ & $1.1 \mathrm{f}$ & 1.03 ef & $0.7 \mathrm{~h}$ \\
\hline
\end{tabular}


growth and enzyme activity is conditioned by the medium type, its $\mathrm{pH}$ and/or incubation temperature on which is cultivated, since environmental factors modulate the fungal response. In the three media analysed, fungal growth was favoured at the highest incubation temperature tested $\left(25^{\circ} \mathrm{C}\right)$, however, most fungi showed higher levels of enzyme activity at $4^{\circ} \mathrm{C}$ than at 15 and $25^{\circ} \mathrm{C}$. This profile of enzymatic activity upon incubation temperature can be related to a behaviour type for these fungi associated to exoskeleton debris of $\mathrm{N}$. granulata as cold-tolerant mesophiles in the sense of Onofri et al. (2004). As other extremophilic microfungi such as Antarctic ones, strains isolated from $N$. granulata debris might to be adapted to live in unstable microenvironments with notorious thermal variations by the effect of climate and possibly by their exposition to natural water level fluctuations on littoral zones of brackish salt marshs where their isolate source (exoskeleton debris) are accumulated in Campos del Tuyú National Park (Argentina) due to hydrologic regimes dependent of environmental conditions. The probable biochemical adaptation of these fungi with higher levels of enzyme activity at lower temperatures might be related to a wide enzymatic competence, that increases survival chances in unfavorable conditions and being able to produce enzymes which are active over a very wide range of temperatures, including low temperatures (Fenice et al. 1998). Also, an increase in enzyme activity from fungal culturesat low temperature might be related to thermal activation processes. Tibbett et al. 1999 observed the activation of certain enzymes at low temperatures in some species of Hebeloma (Basidiomycota), which they also attributed to the characteristics of the habitat from which the fungi were isolated. Elíades et al. 2015 also found that different strains of Humicolopsis cephalosporioides (Ascomycota) isolated from the soil of an Andean-Patagonian forest and exposed to different temperatures showed higher levels of enzyme activity at low temperatures. Romero Núñez 2012 suggested that the activation of fungal enzymes at low temperatures responds to the increase in enzyme catalytic efficiency, which is a physiological adjustment required to achieving their functional action under incubation conditions in which reaction rates are reduced.

Table IV. In vitro extracellular ability of six selected fungi grown on agar media supplemented with Tween 20 , casein and Chitin-Azure ${ }^{\oplus}$ at pH 7 and three different incubation temperatures. The same letters indicate nonsignificant differences $(P \leq 0.05)$.

\begin{tabular}{|c|c|c|c|c|c|c|c|c|c|}
\hline \multirow[b]{4}{*}{ A. alternata } & \multicolumn{9}{|c|}{ Enzyme ability (halo/growth) } \\
\hline & \multicolumn{3}{|c|}{ Tween 20} & \multicolumn{3}{|c|}{ Casein } & \multicolumn{3}{|c|}{ Chitin Azure } \\
\hline & $26^{\circ} \mathrm{C}$ & $16^{\circ} \mathrm{C}$ & $4^{\circ} \mathrm{C}$ & $26^{\circ} \mathrm{C}$ & $16^{\circ} \mathrm{C}$ & $4^{\circ} \mathrm{C}$ & $26^{\circ} \mathrm{C}$ & $16^{\circ} \mathrm{C}$ & $4^{\circ} \mathrm{C}$ \\
\hline & $1.3 \mathrm{bc}$ & $1.1 \mathrm{~b}$ & $1.8 \mathrm{~d}$ & $0.9 b$ & $1.23 d$ & $1.1 \mathrm{bcd}$ & $0 \mathrm{a}$ & $0 \mathrm{a}$ & $0.2 \mathrm{ab}$ \\
\hline C. rosea & $1.3 \mathrm{bc}$ & $1.7 \mathrm{~d}$ & $3.9 f$ & $1.03 \mathrm{bcd}$ & $1.17 \mathrm{~cd}$ & $2.1 \mathrm{f}$ & $0.3 \mathrm{abc}$ & $0.2 \mathrm{ab}$ & $0.8 \mathrm{ab}$ \\
\hline F. equiseti & $0 \mathrm{a}$ & $0 \mathrm{a}$ & $1.5 \mathrm{~d}$ & $0 \mathrm{a}$ & $1.1 \mathrm{bcd}$ & $1.1 \mathrm{bcd}$ & $0.2 a b$ & $0 \mathrm{a}$ & $0,9 \mathrm{~d}$ \\
\hline F. solani & $0 \mathrm{a}$ & $0 \mathrm{a}$ & $1.6 \mathrm{~d}$ & $0 \mathrm{a}$ & $1 b c$ & $1.2 \mathrm{~cd}$ & $0.3 \mathrm{abc}$ & $0.4 a b c$ & $0.7 b c$ \\
\hline P. lilacinum & $1 b$ & $1 \mathrm{~b}$ & $3.9 \mathrm{fe}$ & $1.07 \mathrm{bcd}$ & $1.1 \mathrm{bcd}$ & $1.8 \mathrm{e}$ & $0.6 \mathrm{e}$ & $0 \mathrm{a}$ & $0 \mathrm{a}$ \\
\hline S. brevicaulis & $1.5 \mathrm{~cd}$ & $1.7 \mathrm{~d}$ & $2.9 \mathrm{e}$ & $1 b c$ & $1.1 \mathrm{bcd}$ & $2.2 \mathrm{f}$ & $0.53 a b c$ & $0.2 a b$ & $0.3 a b c$ \\
\hline
\end{tabular}


On the other hand, the fungal response to $\mathrm{pH}$ varied according to the isolate and type of specific substrate in the medium. Fusarium solani LPSC 1422 did not show a negative response to alkaline $\mathrm{pH}$ when grown in tween 20 and casein media, whereas in chitin media, this fungus grew better at pH 8 than at 5 and 10 . Other isolates tested also showed larger halos of enzymatic activity at alkaline than acidic $\mathrm{pH}$, which could be related to the soil pH conditions where the crabs live. Since alkalinization of the medium can facilitate the availability of certain metals that interfere in enzyme induction, activity and stability mainly because of the effect that $\mathrm{H}^{+} / \mathrm{OH}^{-}$concentration has on the availability and ionic forms of nutrients, the ionization of the specific chemical groups of the substrate and the enzymes active sites, as well as on protein denaturation (Saparrat et al. 2007), a link between enzymatic activity and external pH can be inferred. Saparrat et al. 2007 found a direct relationship between the degree of activity of cellulolytic enzymes and the $\mathrm{pH}$ of the reaction they catalyse, which were parameters also related to the alkaline substrates of the source environment of the fungi. Since the $\mathrm{pH}$ of the brackish salt marsh in Campos del Tuyú National Park (Argentina), where exoskeleton debris of $N$. granulata were collected, is a key factor in determining the structure of this edaphic ecosystem (Beade 1981), our results suggest that the enzyme systems of many fungi colonizing exoskeleton debris of the crab might be highly active at alkaline $\mathrm{pH}$. In conclusion, although our results are preliminary, this is the first study that analysed the mycobiota associated with exoskeletons of $N$. granulata. These organic materials dominant in brackish salt marshs in Campos del Tuyú National Park (Argentina) are a source of fungi able to produce enzyme activities that show differences upon incubation conditions to which they are cultivated such as ones including specific temperatures and $\mathrm{pH}$ values. However, further research will deepen our understanding of the physiology and role of the fungi isolated in the mineralization of $\mathrm{N}$. granulata exoskeleton debris.

\section{Acknowledgments}

This research was supported by CONICET (PIP 0018 and PICT 2015-1146), "Comisión de Investigaciones Científicas de la Provincia de Buenos Aires" (CICPBA), UNLP (Projects 11/N 773 and A344), and "Campos del Tuyú" National Park, National Park Administration (APN), Argentina.

\section{REFERENCES}

BARRERA VA, MARTIN ME, AULICINO M, MARTÍNEZ S, CHIESSA G, SAPARRAT MCN \& GASONI AL. 2019. Carbon-substrate utilization profiles by Cladorrhinum (Ascomycota). Rev Agent Microbiol 51: 302-306.

BEADE MS. 1981. Tipos de ambientes naturales en la Reserva de Vida Silvestre Campos del Tuyú. Informe inédito, p. 10.

BORTOLUS A. 2006. The austral cordgrass Spartina densiflora Brong.: its taxonomy, biogeography and natural history. J Biogeogr 33: 158-168.

BOSCHI EE. 1964. Los crustáceos decápodos Brachyura del litoral bonaerense (R. Argentina). Boletín IBM 6: 1-99.

BOTTO F, IRIBARNE O, GUTIERREZ J, BAVA J \& GAGLIARDINI A. 2006. The ecological importance of passive deposition of meiofauna and organic matter into burrows of the SW Atlantic burrowing crab Chasmagnathus granulatus. Mar Ecol Prog Ser 312: 201-210.

BOTTO F, VALIELA I, IRIBARNE O, MARTINETTO P \& ALBERTI J. 2005. Impacto de los cangrejos excavadores en las fuentes de C y N, control y transformaciones en sedimentos y redes alimenticias de los estuarios del Atlántico suroeste. Serie del progreso de la ecología marina 293: 155-164.

CABELLO MN \& ARAMBARRI AM. 2002. Diversity in soil fungi from undisturbed and disturbed Celtis tala and Scutia buxifolia forests in the eastern Buenos Aires province (Argentina). Mycol Res 157: 115-125.

CARMICHAEL JW, KENDRICK WB, CONNERS JL \& SIGLER L. 1980. Genera of Hyphomycetes, Edmonton: The University of Alberta Press, p. 396.

CAROL ES, KRUSE EE \& CELLONE FA. 2015. Salinización de suelos en marismas. Caso de estudio: Humedal de la 
Bahía Samborombón, Argentina. Rev Fac Cienc Agrar 47: 97-107.

DICK RP, THOMAS DR \& TURCO RF. 1996. Standardized methods, sampling, and sampling treatments. In: METHODS FOR ASSESSING SOIL QUALITY. Soil Sci Soc Amer, Madison: Doran JW \& Jones AJ (Eds), p. 107-121.

DOMSCH KH, GAMS W \& ANDERSON T. 1993. Compendium of soil fungi, Eching: IHW-Verlag, p. 672.

ELÍADES L, CABELLO M, VOGET C, GALARZA B \& SAPARRAT $M$. 2010. Screening for alkaline keratinolytic activity in fungi isolated from soils of the biosphere reserve "Parque Costero del Sur" (Argentina). World J Microb Biot 26: 2105-2111.

ELÍADES LA, CABELLO MN, PANCOTTO V, MORETTO A, RAGO MM \& SAPARRAT MC. 2015. Preliminary data on growth and enzymatic abilities of soil fungus Humicolopsis cephalosporioides at different incubation temperatures. Rev Iberoam Micol 32: 40-45.

ELÍADES LA, FERRERI NA, BUCSINSKY AM, SAPARRAT CM \& CABELLO MN. 2014. Micobiota alcalino-tolerante descomponedora de restos de Distichlis spicata (Poaceae) en suelos alcalinos de la Provincia de Buenos Aires: habilidad enzimática. Lilloa 51: 46-53.

ELLIS MB. 1971. Dematiaceous Hyphomycetes, Kew: Common Wealth Mycological Institute, p. 608.

FENICE M, SELBMANN L, DI GIAMBATTISTA R \& FEDERICI F. 1998. Chitinolytic activity at low temperature of an Antarctic strain (A3) of Verticillium lecanii. Res Microbiol 149: 289-300.

FENICE M, SELBMANN L, ZUCCONI L \& ONOFRI S. 1997. Production of extracellular enzymes by Antarctic fungal strains. Polar Biol 17: 275-280.

FRANCO E, TRONCOZO MI, BAEZ M, MIRÍFICO MV, ROBLEDO GL, BALATTI PA \& SAPARRAT MCN. 2018. Fusarium equiseti LPSC1166 and its in vitro role in the decay of Heterostachys ritteriana leaf litter. Folia Microbiol 63: 169-179.

HANKIN L \& ANAGNOSTAKIS SL. 1975. The use of solid media for detection of enzyme production by fungi. Mycologia 67: 597-607.

HOWARD M, EKBORG N, TAYLOR L, WEINER R \& HUTCHESON S. 2003. Detection and characterization of chitinases and other chitin-modifyig enzymes. J Industr Microbiol Biotechnol 30: 627-635.

KONEMAN E \& ROBERTS G. 1987. Micología. Practica de laboratorio, Buenos Aires: Editorial Médica Panamericana SA, p. 221.
LAGE-YUSTY MA, VILASOA-MARTÍNEZ M, ÁLVAREZ-PÉREZ S \& LÓPEZ-HERNÁNDEZ J. 2011. Chemical composition of snow crab shells (Chionoecetes opilio). CyTA-J Food 9: 265-270.

MAGURRAN AE. 1988. Ecological diversity and its measurement, London: Croom Helm, p. 178.

MALLO AC, ELÍADES LA, NITIU DS \& SAPARRAT MCN. 2017. Monitoring indoor air status in the Museo de La Plata Herbarium (LP), Argentina. Rev Iberoam Micol 34: 99-105.

MENDEZ-CASARIEGO A, ALBERTI J, LUPPI T, DALEO P \& IRIBARNE O. 2011. Habitat shifts and spatial distribution of the intertidal crab Neohelice (Chasmagnathus) granulata Dana. J Sea Res 66: 87-94.

NAGAI K, SUZUKI K \& OKADA G. 1998. Studies on the distribution of alkalophilic and alkali-tolerant soil fungi II: Fungal flora in two limestone caves in Japan. Mycoscience 39: 293-298.

NAYAR TS \& JOTHISH PS. 2013. An assessment of the air quality in indoor and outdoor air with reference to fungal spores and pollen grains in four working environments in Kerala, India. Aerobiologia 29: 131-152.

ONOFRI S, SELBMANN L, ZUCCONI L \& PAGANO S. 2004. Antarctic microfungi as models for exobiology. Planet Space Sci 52: 229-237.

PARKINSON D \& WILLIAMS S. 1961. A method for isolating fungi from soil microhabitats. Plant Soil 13: 347-355.

PROMAR-AACS. 1991. Programa de Métodos Analíticos de Referencia. pH, Carbono, Materia orgánica, Nitrógeno total, Fósforo extraíble, Buenos Aires: Ed. Asociación Argentina de la Ciencia del Suelo, Comité de Química.

ROMERO NÚÑEZ M. 2012. Evolución dirigida mediante mutagénesis por saturación de la xilanasa $L$ de origen marino antártico. Available at: http://repositorio.uchile. cl/handle/2250/113507. Accessed on 10 March 2020.

SAMLA. 2004. Sistema de apoyo metodológico a los laboratorios de suelos, agua, vegetales y enmiendas orgánicas, Buenos Aires: Dirección de Agricultura SAGPyA Argentina.

SAPARRAT MCN, ARAMBARRI AM \& BALATTI PA. 2007. Growth response and extracellular enzyme activity of Ulocladium botrytis LPSC 813 cultured on carboxy-methylcellulose under a pH range. Biol Fertil Soils 44: 383-386.

SAPARRAT MCN, ROCCA M, AULICINO MB, ARAMBARRI AM \& BALATTI PA. 2008. Celtis tala and Scutia buxifolia leaf litter decomposition by selected fungi in relation to their physical and chemical properties and lignocellulolytic enzyme activity. Eur J Soil Biol 44: 400-407. 
SPIVAK ED. 2010. The crab Neohelice (=Chasmagnathus) granulata: an emergent animal model from emergent countries. Helgol Mar Res 64: 149-154.

SPIVAK ED. 2016. Los crustáceos de interés pesquero y otras especies relevantes en los ecosistemas marinos. In: BOSCHI EE (Ed), El Mar Argentino y sus Recursos Pesqueros, 6, Mar del Plata: Instituto Nacional de Investigación y Desarrollo Pesquero INIDEP, Mar del Plata, Argentina, p. 15-28.

STEVENSON JR. 1985. Dynamics of the integument. In: Bliss de (Ed), The biology of Crustacea, 9, Integument, pigments, and hormonal processes, New York: Academic Press, New York, USA, p. 1-42.

SWIONTEK BRZEZINSKA M, JANKIEWICZ U \& WALCZAK M. 2013. Biodegradation of chitinous substances and chitinase production by the soil actinomycete Streptomyces rimosus. Internat Biodet Biodeg 84: 104-110.

SWIONTEK BRZEZINSKA M, LALKE-PORCZYK E \& DONDERSKI W. 2008. Utilization of shrimp waste as a respiration substrate by planktonic and benthic microorganisms. Pol J Environ Stud 17: 273-282

TIBBETT M, SANDERS FE, CAIRNEY JWG \& LEAKE JR. 1999. Temperature regulation of extracellular proteases in ectomycorrhizal fungi (Hebeloma spp.) grow in axenic culture. Mycol Res 6: 707-714.

TORZILLI AP, SIKAROODI M, CHALKLEY D \& GILLEVET PM. 2006. A comparison of fungal communities from four salt marsh plants using automated ribosomal intergenic spacer analysis (ARISA). Mycologia 98: 690-698.

VOLPEDO AV, YUNES T \& FERNÁNDEZ CIERELLI A. 2005. El humedal mixohalino de Bahía Samborombón: conservación y perspectivas. In: Petean J \& Cappato J (Eds), Humedales Fluviales de America del Sur. Hacia un manejo sustentable. Ediciones Proteger-UICN, p. 89-110.

WIDDEN P \& PARKINSON D. 1973. Fungi from Canadian coniferous forest soils. Canad J Bot 51: 2275-2290.

\section{How to cite}

FERRERI NA, ELÍADES LA, SAPARRAT MCN, LEDESMA TM, RUSSO L \& CABELLO MN. 2021. Mycobiota on exoskeleton debris of Neohelice granulata in an alkaline-sodic salt marsh: in vitro enzyme ability at different temperatures and Ph. An Acad Bras Cienc 93: e20201159. DOI 10.1590/0001-3765202120201159,

Manuscript received on July 27, 2020;

accepted for publication on January 6, 2021

\section{NATALIA A. FERRERI ${ }^{1}$}

https://orcid.org/0000-0002-1179-8471

\section{LORENA A. ELÍADES 1}

https://orcid.org/0000-0002-9457-0463

\section{MARIO C.N. SAPARRAT ${ }^{2,3}$}

https://orcid.org/0000-0001-7403-1713

TAMARA M. LEDESMA ${ }^{1}$

https://orcid.org/0000-0002-5902-7764

\section{LETICIA RUSSO ${ }^{1}$}

https://orcid.org/0000-0003-0657-4796

\section{MARTA N. CABELLO ${ }^{1, *}$}

https://orcid.org/0000-0003-2208-1991

${ }^{1}$ Instituto de Botánica Carlos Spegazzini, FCNyM-UNLPCICPBA, Calle 53 477, La Plata, 1900, Buenos Aires, Argentina ${ }^{2}$ Instituto de Fisiología Vegetal (INFIVE), UNLP-CCT-CONICET, Diagonal 113 esquina 61, La Plata, 1900, Buenos Aires, Argentina ${ }^{3}$ Cátedra de Microbiología Agrícola, Facultad de Ciencias Agrarias y Forestales, UNLP, Avenida 60 y 119, La Plata, 1900 Buenos Aires, Argentina

Correspondence to: Lorena A. Elíades, Mario C.N. Saparrat E-mail:lorenaeliades@yahoo.com,masaparrat@yahoo.com.ar ${ }^{\star} \mathrm{CICPBA}$

\section{Author contributions}

NAF: participated actively in the samplings, data acquisition in the field, species identification, and statistical analyses. TML, $L A E$, and LR: identified the species, analysed and interpreted the data, and wrote the manuscript draft. MCNS: contributed to the conception and design of assays, analysed the data, and contributed to manuscript drafting. MNC: coordinated the research and contributed to species identification. MNC and MCNS: participated in the final edition of the text and reviewed critically the final version of the text adding a relevant intellectual contribution to the draft.

\section{(cc) BY}

